\title{
A Model System for Study of Sex Chromosome Effects on Sexually Dimorphic Neural and Behavioral Traits
}

\author{
Geert J. De Vries, ${ }^{1}$ Emilie F. Rissman, ${ }^{2}$ Richard B. Simerly, ${ }^{3}$ Liang-Yo Yang, ${ }^{4}$ Elka M. Scordalakes, ${ }^{2}$ \\ Catherine J. Auger, ${ }^{1}$ Amanda Swain, ${ }^{5}$ Robin Lovell-Badge, ${ }^{6}$ Paul S. Burgoyne, ${ }^{6}$ and Arthur P. Arnold ${ }^{4}$ \\ ${ }^{1}$ Center for Neuroendocrine Studies, University of Massachusetts, Amherst, Massachusetts 01003-9333, ${ }^{2}$ Department of \\ Biology, University of Virginia, Charlottesville, Virginia 22904, ${ }^{3}$ Division of Neuroscience, Oregon Regional Primate \\ Research Center, Beaverton, Oregon 97006, ${ }^{4}$ Department of Physiological Science, University of California, Los Angeles, \\ California 90095-1606, ${ }^{5}$ Chester Beatty Labs, Institute of Cancer Research, London SW7 3RP, United Kingdom, and \\ ${ }^{6}$ Division of Developmental Genetics, Medical Research Council National Institute for Medical Research, Mill Hill, London \\ NW7 1AA, United Kingdom
}

We tested the hypothesis that genes encoded on the sex chromosomes play a direct role in sexual differentiation of brain and behavior. We used mice in which the testis-determining gene (Sry) was moved from the $Y$ chromosome to an autosome (by deletion of Sry from the $Y$ and subsequent insertion of an Sry transgene onto an autosome), so that the determination of testis development occurred independently of the complement of $X$ or $Y$ chromosomes. We compared $X X$ and $X Y$ mice with ovaries (females) and $X X$ and $X Y$ mice with testes (males). These comparisons allowed us to assess the effect of sex chromosome complement ( $X X$ vs $X Y$ ) independent of gonadal status (testes vs ovaries) on sexually dimorphic neural and behavioral phenotypes. The phenotypes included measures of male copulatory behavior, social exploration behavior, and sex- ually dimorphic neuroanatomical structures in the septum, hypothalamus, and lumbar spinal cord. Most of the sexually dimorphic phenotypes correlated with the presence of ovaries or testes and therefore reflect the hormonal output of the gonads. We found, however, that both male and female mice with $X Y$ sex chromosomes were more masculine than $X X$ mice in the density of vasopressin-immunoreactive fibers in the lateral septum. Moreover, two male groups differing only in the form of their Sry gene showed differences in behavior. The results show that sex chromosome genes contribute directly to the development of a sex difference in the brain.

Key words: Y chromosome; $X$ chromosome; sexual differentiation; lateral septum; androgens; sex chromosome; Sry; sex determination
All sex differences in mammalian and avian development originate ultimately from the action of genes located on the sex chromosomes. For example, the Y-linked gene Sry directs the sexual differentiation of the mammalian gonad by committing that tissue to a testicular rather than ovarian pattern of development (Goodfellow and Lovell-Badge, 1993). Once testes or ovaries develop, however, differences in their secretions induce sexual differentiation of non-gonadal tissues (Jost, 1958), including the brain. Testosterone, or its metabolites such as estradiol, act on the brain during critical periods of development to induce masculine patterns of neural differentiation that lead to sex differences in brain and behavior (Phoenix et al., 1959; Goy and McEwen, 1980; Arnold and Gorski, 1984).

In some cases, however, sexual dimorphisms in non-gonadal tissues are difficult or impossible to explain as the result of gonadal steroid action. (1) In several mammalian species, male

Received Jan. 31, 2002; revised July 16, 2002; accepted July 22, 2002.

This work was supported by National Institutes of Health (NIH) Grants R01 MH57759 and K02 MH01349, and by National Institute of Child Health and Human Development/NIH through cooperative agreement U54 HD28934 as part of the Specialized Cooperative Centers Program in Reproduction Research. Islet-1 antibodies were developed by J. Ericson, S. Thor, T. Edlund, T. M. Jessell, and T. Yamada and obtained from the Developmental Studies Hybridoma Bank maintained by The University of Iowa, Department of Biological Sciences (Iowa City, IA), under contract NO1-HD-7-3263. We thank Nancy Forger, Xia Li, and Melissa Kirigiti for assistance.

Correspondence should be addressed to Geert J. De Vries, Center for Neuroendocrine Studies, Department of Psychology, University of Massachusetts, Amherst MA 01003-9333. E-mail: devries@cns.umass.edu.

Copyright (C) 2002 Society for Neuroscience $\quad 0270-6474 / 02 / 229005-10 \$ 15.00 / 0$ embryos develop faster than female embryos (Erickson, 1997) before differentiation of the gonads. X- and Y-linked genes contribute to this sex difference (Burgoyne et al., 1995). (2) In the tammar wallaby, several sexually dimorphic structures, such as pouch and scrotum, differentiate before the gonads have differentiated (Renfree and Short, 1988). (3) Neurons dissociated from embryonic male or female rat brain cultured under identical conditions nevertheless grow in a sexually dimorphic manner, with female cultures developing more tyrosine hydroxylase $(\mathrm{TH})$ or prolactin-immunoreactive neurons, although the cells are harvested before the onset of sexually dimorphic gonadal secretions (Beyer et al., 1991, 1992a,b). (4) Numerous X-linked genes are expressed differently in males and females and can lead to sex differences in traits. In New World primates, for example, females express more X-linked photopigment alleles than males, which generates a sex difference in retinal photosensitivity (Jacobs, 1998; Dulai et al., 1999). (5) In zebra finches, genetic females that possess testes develop a feminine neural circuit for song (Wade and Arnold, 1996), and it has so far proved difficult to prevent masculine neural differentiation by manipulating gonadal steroid action in genetic males (Arnold, 1997).

Comparisons of behavioral phenotypes across mouse strains have revealed that the $\mathrm{Y}$ chromosome encodes genes that influence specific sexually dimorphic behaviors or neural phenotypes (Maxson, 1992, 1996a,b; Guillot et al., 1995; Hensbroek et al., 1995; Sluyter et al., 1995, 1996). Y chromosome dosage also appears to have significant behavioral effects in humans (Ratcliffe 
et al., 1990). These studies support a role for the Y chromosome in the development of male neural and behavioral phenotypes.

In the present paper we introduce a powerful mouse model system for testing the idea that $\mathrm{X}$ - or Y-linked genes contribute directly to sexual differentiation of the brain via nonhormonal mechanisms. Our test involves comparisons of the brain and behavior of mice that have the same gonads but possess different complements of sex chromosomes. We identify one sexual dimorphism in brain, the density of vasopressin (VP)-immunoreactive (ir) fibers in the lateral septum, which is more masculine in mice with XY sex chromosomes than in mice with XX chromosomes. The difference is likely a direct effect of genes encoded on the sex chromosomes.

\section{MATERIALS AND METHODS}

\section{Mouse stocks}

All mice were random-bred MF1 except for the Y chromosome, which derived from strain 129 (129/SvEv-Gpi1 ${ }^{c}$ Y) (Simpson et al., 1999). Some mice possessed a variant of $\mathrm{Y}^{129}$ deleted for the testis-determining gene Sry $\left[T d y^{m 1}\right.$ mutation of Lovell-Badge and Robertson (1990); Gubbay et al. (1992)], here designated $\mathrm{Y}^{-}$. Thus, $\mathrm{XY}^{-}$mice are female (defined by the presence of ovaries). In some mice an Sry transgene was inserted into an autosome, creating $\mathrm{XY}^{-}$Sry mice that possess testes and are fully fertile males (Mahadevaiah et al., 1998). XY ${ }^{-}$Sry males were bred with normal MF1 XX females to produce four genotypes: XX females, $\mathrm{XY}^{-}$ females, XY-Sry males, and XXSry males. Comparison of these four groups (using two-way ANOVAs; see below) allowed assessment of the independent effects of sex (male vs female) and sex chromosome complement $\left(\mathrm{XY}^{-}\right.$vs XX) and their interaction. All four genotypes occur in the same litters so that prenatal and postnatal environment and litter effects are distributed across groups. In addition, $\mathrm{XY}^{129}$ males (MF1 males of the same strain as the other mice except that the $Y^{129}$ chromosome was not deleted for Sry) were compared with $\mathrm{XY}^{-}$Sry males to test for any differences attributable to the different Sry genes (transgenic vs endogenous).

\section{Experiment 1}

Mice were bred at the Medical Research Council National Institute for Medical Research. Genotype was determined by PCR analysis of the presence of the Y long-arm gene family Ssty and of the Sry transgene at the time of weaning and again after behavioral analysis. As adults (7-8 weeks of age) the mice were shipped to the University of Virginia (Charlottesville, VA), where they were tested for aggression, copulatory behavior, and social exploration. The results on aggressive behavior will be presented in a separate publication. The mice were anesthetized and perfused with fixative (see below). Fixed brains and spinal cords were shipped to other laboratories for histological analysis of several sexually dimorphic neural systems, including the vasopressin (VP) innervation of the lateral septum, tyrosine hydroxylase (TH)-immunoreactive (ir) neurons of the anteroventral periventricular nucleus of the preoptic region (AVPV), and the spinal nucleus of the bulbocavernosus (SNB), as described below. All handling of mice and analyses were conducted by investigators who were unaware of the genotypes of the mice. At the University of Virginia, males were housed individually. Females were housed in groups of two to three for 2 months until they were treated as described below and housed individually. Mice were housed on a $12 \mathrm{hr}$ light/dark cycle (lights off at 1:00 P.M. EDT) and received ad libitum access to food (Purina mouse chow 5001) and water.

Behavioral tests: surgery, hormone treatment, and social exposure. Mice used as experimental subjects were gonadectomized bilaterally. Testes were collected and weighed for later indirect check of genotype (XXSry males have smaller testes than $\mathrm{XY}^{-}$Sry males). Surgery was conducted under ketamine/xylazine anesthesia (xylazine, $100 \mathrm{mg} / \mathrm{kg}$; ketamine, 10 $\mathrm{mg} / \mathrm{kg}$ ). At the time of surgery each mouse received a subcutaneous SILASTIC capsule $[1.02 \mathrm{~mm}$ inner diameter (id) $\times 2.16 \mathrm{~mm}$ outer diameter (od)] in the midscapular region filled with $7 \mathrm{~mm}$ of testosterone. For the behavior tests, the group sizes were $\mathrm{XY}=10, \mathrm{XY}^{-}$Sry $=17$, $\mathrm{XXSry}=15, \mathrm{XY}^{-}=19$, and $\mathrm{XX}=17$.

Stimulus animals. One week after surgery each animal was given exposure to other mice $3-5 \mathrm{hr}$ before the dark cycle (Wersinger et al., 1997). Gonad-intact C57BL/6J males served as stimulus animals for both social exposure and social exploration tests. For the social exposure and sex behavior tests, female C57BL/6J adults were ovariectomized and received a subcutaneous implant of estradiol benzoate dissolved in sesame oil $(50 \mu \mathrm{g}$ in $0.025 \mathrm{ml})$ infused into a SILASTIC implant (1.98 $\mathrm{mm}$ id $\times 3.17 \mathrm{~mm}$ od) sealed with SILASTIC adhesive. The females received a subcutaneous injection of progesterone (P) $[100 \mu \mathrm{g}$ in $0.025 \mathrm{ml}$ sesame oil; method of Rissman et al. (1997)] 2-5 hr before each sex test. These same females were also used for social exploration tests, in which no $\mathrm{P}$ injections were given.

Masculine mating tests. Starting 3 weeks after gonadectomy, each mouse was tested for masculine sexual behavior beginning $2-3 \mathrm{hr}$ after the start of the dark cycle according to the procedure of Wersinger and Rissman (2000a). Briefly, tests were conducted in the dark in clear Plexiglas cages $(18 \times 38 \mathrm{~cm})$ placed on a mirror stand to allow ventral viewing and permit the observer to distinguish between mounts with or without intromission. The tests lasted for $30 \mathrm{~min}$, or until the test animal ejaculated. If the pair was engaged in mounting at the end of $30 \mathrm{~min}$, the test was continued until either the test animal ejaculated or the pair stopped interacting for $5 \mathrm{~min}$. During the tests, the latencies and numbers of each attempted mount, mounts with thrusts, mounts with intromission, and ejaculation were recorded as were the numbers of thrusts and intromissions per mount. For data analysis of behavioral latencies and frequencies, only tests that included the behavior of interest were scored.

Social exploration tests. Social exploration was tested 1 week after the sexual behavior test $2-3 \mathrm{hr}$ after the start of the dark cycle, using a procedure described in Wersinger and Rissman (2000b). A Plexiglas test box was divided into three areas. Anesthetized stimulus mice were placed in each of the two end chambers, an intact male at one end and an ovariectomized estrogen-implanted female at the other end. The number of visits to each stimulus animal, the total amount of time spent with stimulus animals, and the amount of time each mouse spent sniffing each stimulus animal were recorded (Wersinger and Rissman, 2000b). The social exploration test is sensitive to central processing of social stimuli, but also to individual differences in basic sensory processing, for example in olfactory sensitivity.

Tissue collection. At the end of behavioral testing the mice were anesthetized with sodium pentobarbital. Blood was collected for testosterone radioimmunoassay. The mice were perfused briefly with $0.9 \%$ saline followed by $5 \%$ acrolein in $0.1 \mathrm{M}$ sodium phosphate buffer $(\mathrm{PB})$, $\mathrm{pH}$ 7.6. The bodies of the mice were sent to the University of California Los Angeles for histological analysis of the SNB. Fixed brains were placed in a solution of $30 \%$ sucrose in $\mathrm{PB}$ and shipped to the University of Massachusetts (Amherst, MA). Brains were blocked into 2- to 4-mmthick transverse slices. The slices that included the septum and the AVPV were split into a dorsal and ventral half by a horizontal cut at the level of the crossing of the anterior commissure. The portion containing the AVPV was frozen and shipped to the Oregon Regional Primate Research Center (Beaverton, OR) for analysis of TH immunoreactivity in the AVPV. The other samples were stored in PB-buffered sucrose solution at $4^{\circ} \mathrm{C}$ until they were sectioned transversely at $35 \mu \mathrm{m}$ with a freezing microtome for analysis of VP immunoreactivity in the lateral septum.

Testosterone radioimmunoassay. Testosterone levels were determined by radioimmunoassay conducted by the University of Virginia Core Ligand and Assay Laboratory (Charlottesville, VA). Samples were run in duplicate in a single assay. The range of the assay was from 0.1 to 25.0 $\mathrm{ng} / \mathrm{ml}$. The average intra-assay coefficient of variability was $10.8 \%$. Two animals were excluded from further analysis because they possessed exceptionally high levels of testosterone at the time they were killed.

Vasopressin immunocytochemistry. Sections were processed for VP immunoreactivity at room temperature unless stated otherwise. VP immunoreactivity was located with rabbit anti-VP serum (ICN Laboratories, Costa Mesa, CA) in a 1:4000 dilution for $90 \mathrm{~min}$ at $37^{\circ} \mathrm{C}$, followed by detection of the primary antibody by biotinylated goat anti-rabbit serum (Vector Laboratories, Burlington, CA) and the avidin-biotin complex ABC detection system (Vector Elite Kit, Vector Laboratories) followed by visualization of the antibody complex using nickel-intensified DAB as the chromogen as described in Villalba et al. (1999). Microscopic images were captured under bright-field illumination using a CCD camera linked to a computer. The density of VP-ir fibers in the lateral septum was examined in the section that contained the highest fiber density in these areas [corresponding to Fig. 30 in the atlas of Paxinos and Franklin (1998)]. Fiber density was analyzed by computerized graylevel thresholding using the NIH Image software. The light intensity and camera setting were kept constant across the sections to standardize measurements. Fiber density was expressed as the number of pixels 
covered by VP-ir fibers in an image of a 0.25 -mm-square sampling area immediately bordering the ventricular wall. Group sizes were $X Y=10$, $\mathrm{XY}^{-}$Sry $=17, \mathrm{XXSry}=13, \mathrm{XY}^{-}=15$, and $\mathrm{XX}=13$.

Tyrosine hydroxylase histochemistry of the AVPV. To determine the number of dopaminergic neurons in the AVPV of each animal, $20-\mu \mathrm{m}-$ thick frozen sections through the preoptic region were cut on a sliding microtome and collected in chilled potassium PBS. Dopaminergic neurons were labeled by incubating tissue sections at $4^{\circ} \mathrm{C}$ for $72 \mathrm{hr}$ in a $1: 1000$ dilution of an antiserum directed against TH (EugeneTech, Allendale, $\mathrm{NJ}$ ), which was localized with an affinity-purified goat anti-rabbit IgG conjugated with fluorescein isothiocyanate (BioSource International, Camarillo, CA) as described in detail previously (Sawchenko and Swanson, 1981). The sections were mounted, counterstained with ethidium bromide for cytoarchitectonic orientation (Schmued et al., 1982), and coverslipped with buffered glycerol. The number of TH-ir neurons within the AVPV was counted in every third section using fluorescence microscopy and then corrected with Abercrombie's method (Abercrombie, 1946). The counted objects did not differ in size, and the section thickness did not vary between experimental groups; thus the results provide estimates of the relative number of TH-ir neurons in different groups, not absolute cell numbers. The group sizes were $\mathrm{XY}=8, \mathrm{XY}^{-}$Sry $=11$, $\mathrm{XXSry}=13, \mathrm{XY}^{-}=16$, and $\mathrm{XX}=14$.

Spinal nucleus of the bulbocavernosus. Motoneurons were discriminated from non-motoneurons in the region of the SNB using immunostaining for Islet-1, a motoneuronal marker (Ericson et al., 1992, 1996). The lumbosacral region of spinal cords was immersed in $30 \%$ sucrose in $0.1 \mathrm{M} \mathrm{PB}$ and then frozen-sectioned horizontally on a sliding microtome at $40 \mu \mathrm{m}$ and processed for Islet-1-like immunoreactivity at room temperature. After three rinses in $0.05 \mathrm{M}$ Tris-buffered saline (TBS), sections were incubated in $1 \%$ sodium borohydride (in $0.1 \mathrm{M} \mathrm{PB}$ ). Sections were then incubated in TX100 solution ( 0.05 M TBS with $0.3 \%$ Triton X-100) with $4 \%$ normal horse serum (NHS) and 1\% hydrogen peroxide for 30 min and then reacted with mouse anti-Islet-1 antibody (39.4D5, Developmental Studies Hybridoma Bank, Department of Biological Sciences, University of Iowa, Iowa City, IA) at a concentration of 1:80 in TX100 solution with $2 \%$ NHS for $60 \mathrm{~min}$. Sections were then incubated with the secondary antibody (horse anti-mouse IgG; Vector Elite Kit, Vector Laboratories) in TX100 solution with $2 \%$ NHS for 60 min and reacted with $\mathrm{ABC}$ reagent, and then $0.05 \mathrm{M}$ TBS with $0.05 \% \mathrm{DAB}$ and $0.003 \%$ $\mathrm{H}_{2} \mathrm{O}_{2}$. Some spinal sections were processed without the primary or secondary antibody, in which case no Islet-1-like staining was observed.

SNB motoneurons were counted within eight consecutive sections comprising a $320-\mu \mathrm{m}$-thick horizontal slab with as most dorsal limit the section that contained the most dorsal Islet-1-ir cells ventral to the central canal. Cells were counted only if they expressed Islet-1immunoreactivity and were located within $175 \mu \mathrm{m}$ of the midline and were between the lumbar enlargement and the level of the sacral region at which the spinal cord width was $>1.2 \mathrm{~mm}$. In addition, nuclear size and diameter of 20 Islet-1-positive neurons was measured by using NIH Image morphometric software. Abercrombie's correction was used to correct neuron number (Abercrombie, 1946). The group sizes were $\mathrm{XY}=9, \mathrm{XY}^{-}$Sry $=9, \mathrm{XXSry}=8, \mathrm{XY}^{-}=9$, and $\mathrm{XX}=9$.

Statistical tests. All data were analyzed by ANOVAs followed by planned comparisons (Tukey-Kramer tests) to test for differences between pairs of groups. Some of the behavioral data were analyzed by ANOVA on ranks if they failed to meet criteria for a normal distribution. For all analyses except that of VP-ir fibers in the lateral septum (see experiment 2), two basic ANOVAs were run. The first was a two-way ANOVA on the four groups of mice that were progeny of $\mathrm{XY}^{-}$Sry fathers and $\mathrm{XX}$ mothers, with two factors of sex chromosome complement $\left(\mathrm{XY}^{-}\right.$vs XX) and sex (male vs female or Sry vs no Sry). This analysis allowed us to determine whether there was a main effect of sex that would indicate a phenotypic difference correlating with the presence of testes or ovaries, or a main effect of sex chromosome complement $\left(\mathrm{XY}^{-}\right.$vs $\left.\mathrm{XX}\right)$, or an interaction. The predictions of the present paper were that (1) there would be a main effect of sex chromosomes or an interaction of sex chromosomes and sex, or both, and (2) planned comparisons would show a difference between $\mathrm{XY}^{-}$Sry males and $\mathrm{XX}$ Sry males, or between $\mathrm{XY}^{-}$females and $\mathrm{XX}$ females, or both. The second analysis was a one-way ANOVA comparing two male groups (XY vs $\mathrm{XY}^{-}$Sry), which tests whether the Sry transgene has a different effect than the endogenous Sry on the dependent variables measured. Our hypothesis was that there would be no difference in that analysis. When we found a significant difference between male groups, we conducted a further nested ANOVA with litter as the nested variable. This analysis determined whether within-group differences among litters could be eliminated as a significant contributor to the between-group difference and whether the difference was robust enough to survive the loss of power that is inherent in the nested analysis. The $\alpha$ level for all tests was 0.05 .

\section{Experiment 2}

A second experiment was run to replicate the finding in the first experiment that there was a significant effect of sex chromosome complement on VP-ir fiber density in the lateral septum. Mice of the same genotypes as in experiment 1 were bred at National Institute for Medical Research (NIMR; Mill Hill, London, UK) and then shipped to the University of Massachusetts. There they were gonadectomized and implanted with SILASTIC capsules filled with $\mathrm{T}$ as in experiment 1 . Three weeks later, the mice were killed and processed for $\mathrm{VP}$ immunoreactivity as in experiment 1 . The tissue of one XXSry male was excluded from analysis because of excessively high background staining. The statistical analysis of VP-ir paralleled that for other dependent variables, except that experiment number was included as a third factor and data were standardized per experiment as $z$-scores $(z=(x-m)$ /sec where $m=$ group mean and $s=$ standard deviation). Thus, we conducted a three-way ANOVA on the $\mathrm{XY}^{-}$versus $\mathrm{XX}( \pm$ Sry) genotypes [three factors were sex chromosomes ( $\mathrm{XX}$ vs $\mathrm{XY}^{-}$), sex (male vs female), and experiment number]. A second, two-way ANOVA was used to compare $X Y$ and $\mathrm{XY}^{-}$Sry groups in the two experiments [factors were Sry (endogenous Sry in XY vs Sry transgene in XY ${ }^{-}$Sry) and experiment number]. Group sizes were $\mathrm{XY}=7, \mathrm{XY}^{-}$Sry $=7, \mathrm{XXSry}=8, \mathrm{XY}^{-}=10$, and $\mathrm{XX}=10$.

\section{Experiment 3}

The first two experiments showed opposite differences between $X^{-}$ females and XX females in the density of VP-ir fibers in the lateral septum. To test the hypothesis that this inconsistency was the result of variability induced by uncontrolled exposure of fetal females to androgens originating from adjacent males in utero (vom Saal and Bronson, 1978), litters of mice were produced containing only females. $\mathrm{XY}^{-} \mathrm{Yq}$ del $^{\text {RIII }}$ males (Mahadevaiah et al., 2000) were mated to MF1 females. The Yq-del chromosome is of RIII strain origin and carries a deletion of Yq (Conway et al., 1994). Although initially sterile, older males become fertile because of random loss of one or the other $\mathrm{Y}$ in a proportion of spermatogonia. Most of these males produce only female offspring ( $\mathrm{XX}$ and $X Y^{-}$genetically identical to those in experiments $1-3$ ), apparently because of selection against Yq-del sperm in the female tract (P. S. Burgoyne, unpublished results). Mice were bred at NIMR. In experiment 3A they were shipped to the University of Virginia where they underwent surgery, hormone implantation, and behavioral testing similar to that described for experiment 1 (data not shown), after which fixed brains were shipped to the University of Massachusetts for analysis of septal VP-ir fiber density. In experiment 3B the mice were shipped directly to the University of Massachusetts, where they were treated as in experiment 2 before measuring septal VP-ir fiber density. A two-way ANOVA was used to compare $\mathrm{XX}$ and $\mathrm{XY}^{-}$groups in the two experiments (factors were sex chromosome complement, $\mathrm{XX}$ vs $\mathrm{XY}^{-}$, and experiment number). The group sizes were $\mathrm{XX}=7$ and 16 and $\mathrm{XY}^{-}=$ 7 and 17 in experiments $3 \mathrm{~A}$ and $3 \mathrm{~B}$, respectively.

\section{RESULTS \\ Experiment 1}

\section{Testosterone levels}

At the time the mice were killed, plasma testosterone levels were not statistically different among the groups because they all had received identical treatment with testosterone during testing: $\mathrm{XY}$ males $(2.17 \pm 0.27 \mathrm{ng} / \mathrm{ml}$; mean $\pm \mathrm{SEM}), \mathrm{XY}^{-}$Sry males $(2.21 \pm$ $0.13)$, XXSry males (1.81 \pm 0.13$), \mathrm{XY}^{-}$females (3.01 \pm 0.61$)$, and $\mathrm{XX}$ females $(3.68 \pm 1.27)$. The slightly higher but not significantly different levels in females, if anything, would tend to diminish any sex differences in dependent variables that are sensitive to both adult and perinatal circulating levels of testosterone, such as the density of VP-ir fibers in the lateral septum. It should not influence, however, phenotypes that are insensitive to the level of testosterone in adulthood, for example, the numbers of neurons in the SNB or AVPV. 


\section{Masculine sexual behavior}

In analyses of specific behaviors we included only data from mice that displayed the behavior. Female mice had shorter latencies to mount than did males and also shorter latencies to mount with thrusts (Fig. 1). There was a main effect of sex on latency to mount $\left(F_{(1,59)}=19.42 ; p<0.00005\right)$ but no significant effect of sex chromosomes or a significant interaction. The same pattern was found for latency to thrust: a main effect of $\operatorname{sex}\left(F_{(1,45)}=6.02\right.$; $p<0.02$ ) (Fig. 1), but no significant effect of sex chromosomes or a significant interaction. Mount latencies were not different between $\mathrm{XY}$ and $\mathrm{XY}^{-}$Sry males, but $\mathrm{XY}^{-}$Sry males began thrusting sooner than XY males $\left(F_{(1,21)}=6.05 ; p<0.025\right)$. The latter difference was also significant when a nested ANOVA was performed $\left(F_{(1,21)}=6.11 ; p<0.04\right)$. Although XY males began thrusting later than $\mathrm{XY}^{-}$Sry males, they tended to ejaculate sooner $\left(F_{(1,16)}=4.31 ; p=0.057\right)$.

Males displayed more total mounts than females $\left(F_{(1,67)}=\right.$ 12.13; $p<0.001$ ) (Fig. 2), but there was no significant effect of sex chromosomes or a significant interaction. None of the other behavioral measures (frequencies of mounts with thrusts or numbers of mounts in the first 30 min after mating) common to both males and females were significantly different. Total numbers of mounts tended to be greater for $\mathrm{XY}^{-}$Sry males than for $\mathrm{XY}$ males $\left(F_{(1,23)}=4.07 ; p=0.057\right)$ (Fig. 2$)$, but none of the other variables showed any statistically significant differences. There was a trend for the interval between the onset of intromissions and ejaculation to be shorter in XY males (32.2 $\pm 8.4 \mathrm{~min})$ than in $\mathrm{XY}^{-}$Sry males $\left(66.6 \pm 6.95 \mathrm{~min} ; F_{(1,17)}=4.28 ; p=0.056\right)$.

To determine whether animals of different genotypes were more or less likely to engage in certain types of masculine behavior, we conducted $\chi^{2}$ and Fisher exact tests. When a $2 \times 2$ analysis was done to examine the effect of sex chromosomes or an interaction of sex chromosomes and sex, we found that the numbers of mounters and nonmounters did not differ among the four groups. However, when we examined the frequency of animals that did and did not display mounts with thrusts, we found that males were more likely to thrust than females $\left(\chi^{2}(3)=13.3 ; p<\right.$ $0.01)$. No differences were found in the frequencies of $X Y$ and $\mathrm{XY}^{-}$Sry males that mounted, mounted with thrusts, mounted with intromissions, or ejaculated.

\section{Social exploration}

Males spent significantly more total time sniffing, particularly sniffing stimulus females, than did females (main effect of sex, $F_{(1,62)}=13.60,18.37$ for all sniffing and sniffing a female, respectively; $p<0.0005$ ) (Fig. 3), but there were no significant effects of sex chromosomes nor was there an interaction. There was a trend for a sex difference in the total number of visits [males visited more than females $\left(F_{(1,68)}=3.94 ; p=0.051\right)$ ] (Fig. 4$)$, and males visited stimulus males more often than did females (main effect of sex, $\left.F_{(1,68)}=4.27 ; p<0.05\right)$ (Fig. 4). XY males did more visiting and visited the anesthetized males more frequently than did the $\mathrm{XY}{ }^{-}$Sry males $\left(F_{(1,25)}=5.37,4.68\right.$, respectively; $\left.p<0.042\right)$ (Fig. $4)$. When the male groups were compared using a nested ANOVA, the difference was also significant for visits to the male $\left(F_{(1,25)}=5.32 ; p<0.044\right)$. A trend in this same direction was noted for visits to the female $\left(F_{(1,25)}=3.62 ; p=0.07\right.$; data not shown).

\section{Spinal nucleus of the bulbocavernosus}

The number of SNB motoneurons was greater in males than in females (Fig. 5), replicating the sex difference found in rats and
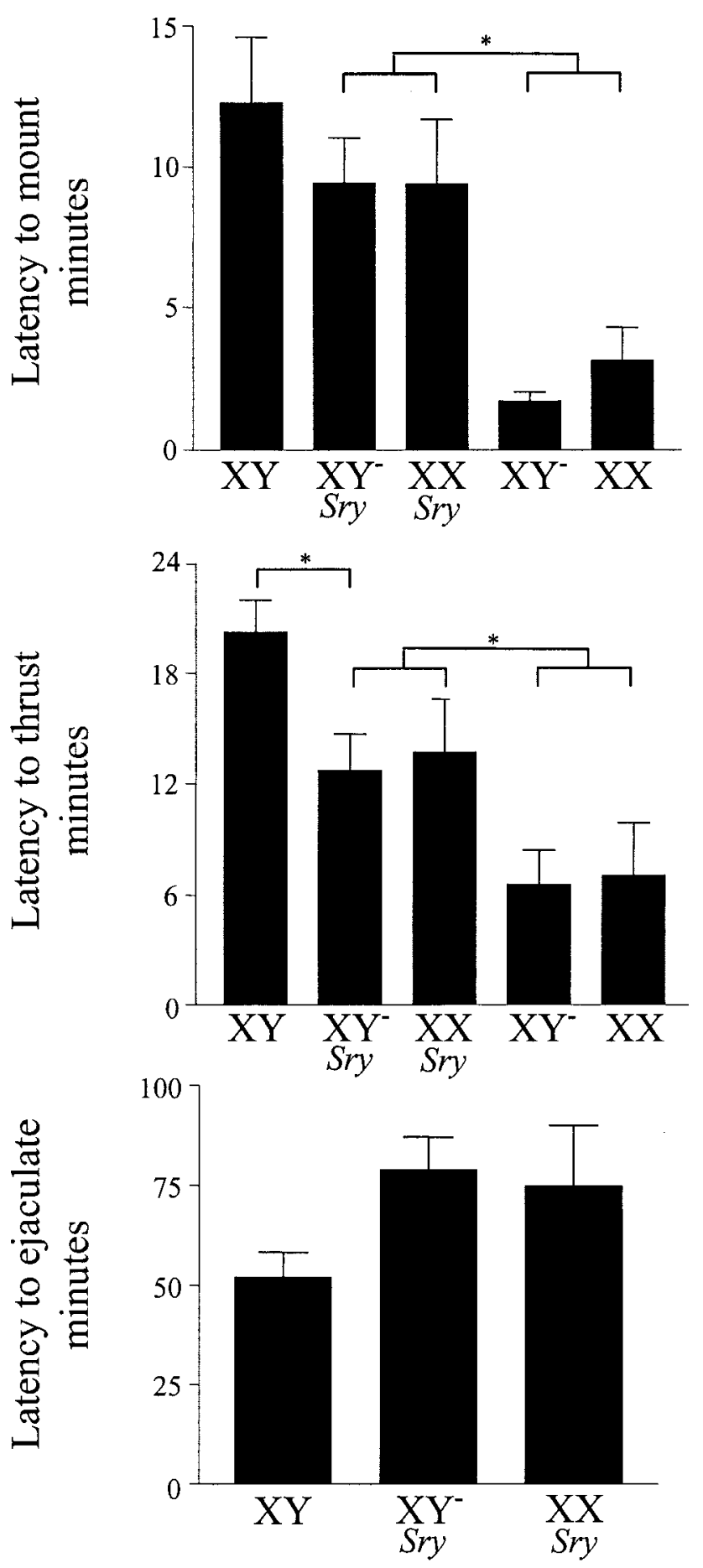

Figure 1. Latencies to mount, thrust, and ejaculate during sex behavior tests (means \pm SEM). Within the four genotypes generated in the core cross, males ( $\mathrm{XY}^{-}$Sry and XXSry) had longer latencies to mount and to thrust than did females $\left(\mathrm{XY}^{-}\right.$and $\left.\mathrm{XX}\right)(p<0.00005)$. XY males, which derived from a different cross, had longer latencies to mount than $\mathrm{XY}^{-}$Sry males. Group sizes left to right were as follows: $8,15,16,15$, and 13 for latency to mount; 7, 14, 14, 10, 7 for latency to thrust; 5, 11, and 10 for latency to ejaculate.

mice (Breedlove and Arnold, 1980; Wee and Clemens, 1987; Hauser and Toran-Allerand, 1989; Wagner and Clemens, 1989). In the two-way ANOVA, there was a significant effect of sex $\left(F_{(1,31)}=33.9 ; p<0.0001\right)$, but no significant effect of sex 


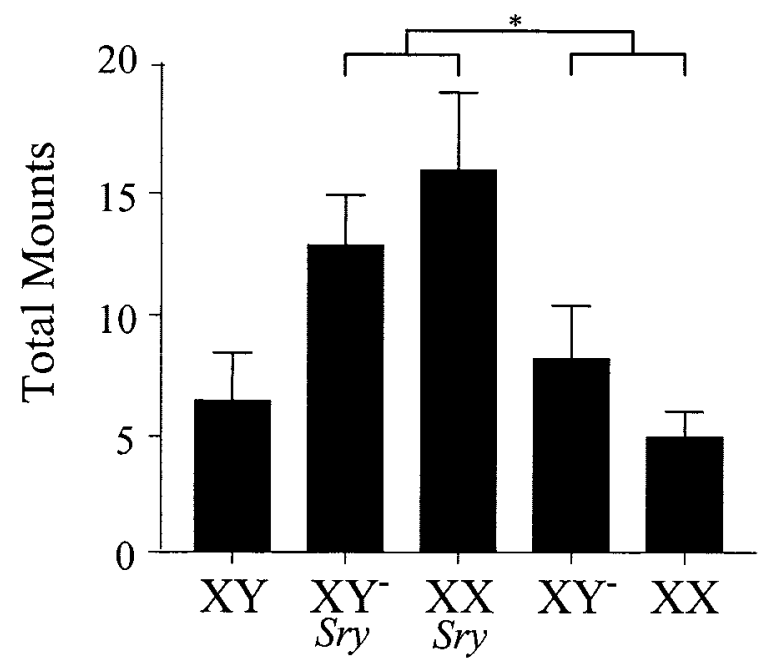

Figure 2. Total mounts (means \pm SEM) during sexual behavior tests with receptive female partners. Within the core cross, males $\left(\mathrm{XY}^{-}\right.$Sry and XXSry) mounted more than did females (XY ${ }^{-}$and $\left.\mathrm{XX}\right)(p<0.001)$. Groups sizes for groups left to right were $8,15,16,15$, and 13 .

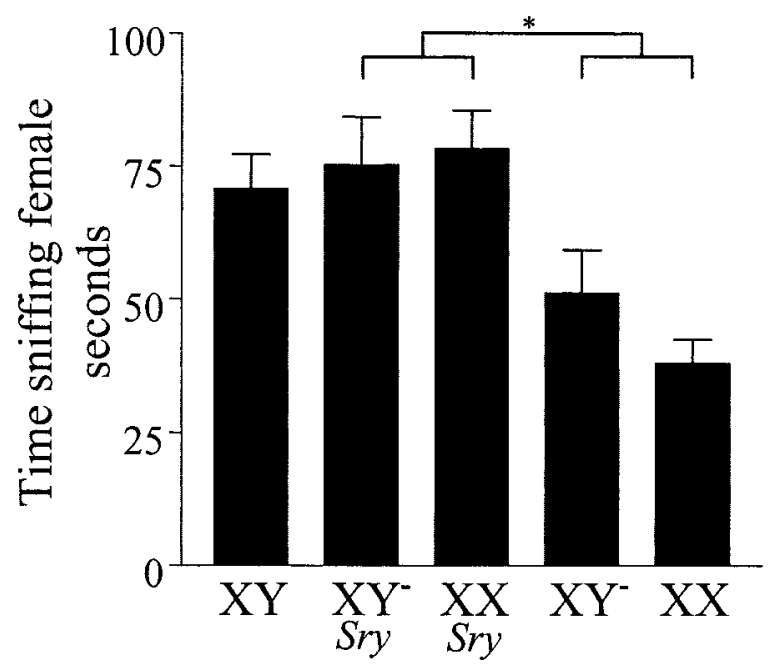

Figure 3. Time spent sniffing an anesthetized female in a $10 \mathrm{~min}$ social exploration test (means \pm SEM). Within the core cross, males $\left(\mathrm{XY}^{-}\right.$Sry and XXSry) spent more time sniffing the stimulus female than did females $\left(\mathrm{XY}^{-}\right.$and $\left.\mathrm{XX}\right)(p<0.0005)$.

chromosomes and no significant interaction. The male groups did not differ significantly from each other.

\section{TH-ir neurons in the AVPV}

Among the four genotypes that were progeny of $\mathrm{XY}^{-}$Sry fathers, females ( $\mathrm{XX}$ and $\mathrm{XY}^{-}$) had more TH neurons in the AVPV than did their brothers $\left(\mathrm{XY}^{-}\right.$Sry and XXSry) $\left(F_{(1,50)}=\right.$ 27.8; $p=0.000003$ ) (Fig. 6). There was no significant effect of sex chromosomes and no significant interaction. XY males were significantly different from $\mathrm{XY}^{-}$Sry males in both the basic and nested ANOVAs $\left(F_{(1,19)}=9.23\right.$ and $\left.13.2 ; p<0.008\right)$. Related to this is the result that XY males did not differ from $\mathrm{XX}$ in the number of $\mathrm{TH}$-ir neurons, in distinct contrast to C57BL/6 mice, which show a difference between XX and XY (Simerly et al., 1997).
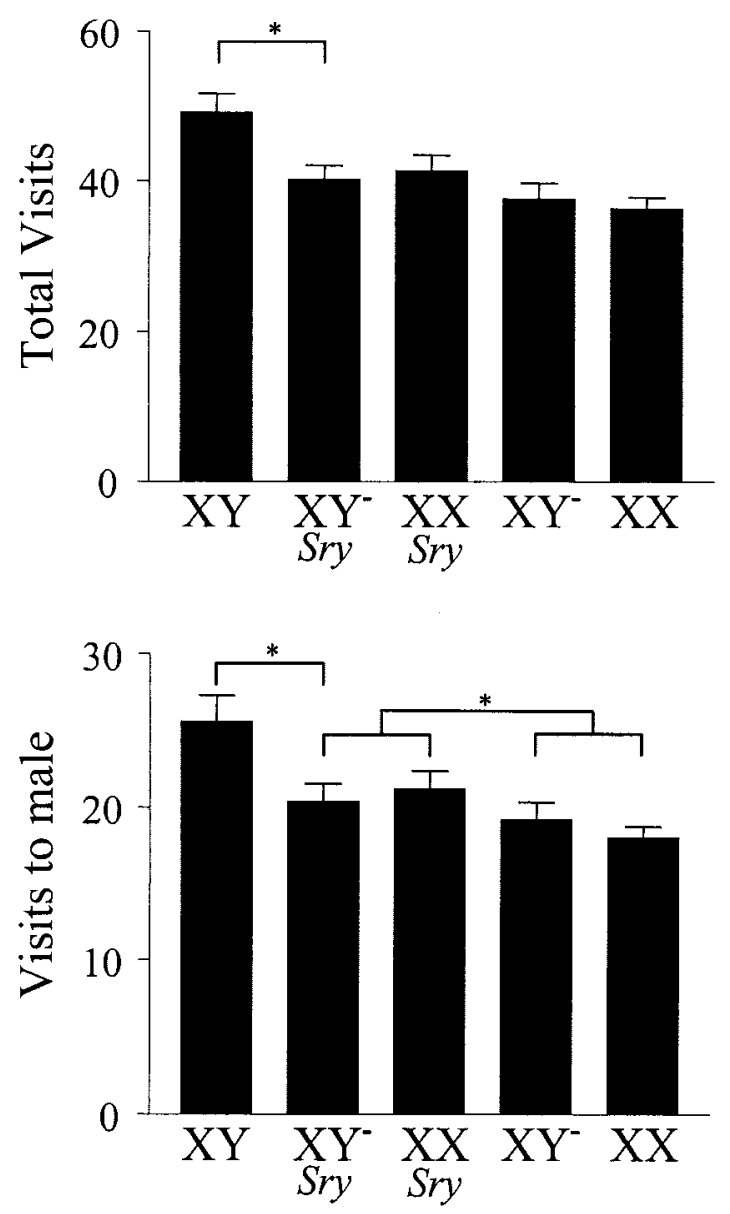

Figure 4. Numbers of visits (means \pm SEM) to the chambers in the three-chambered box, regardless of whether it contained a male or female stimulus animal (top), and visits to the chamber that contained the anesthetized male in the social exploration tests. Males (XY-Sry and $\mathrm{XXSry}$ ) paid more visits to the stimulus male than did females $\left(\mathrm{XY}^{-}\right.$and $\mathrm{XX})(p<0.05)$. XY males paid more visits to the chambers with the stimulus male or female and also visited the stimulus male more often than did $\mathrm{XY}^{-}$Sry males $(p<0.05)$.

\section{Experiments 1-3}

Vasopressin fiber density in the lateral septum

In Experiment 1, the tissue for males and females was fixed and immunostained at different times, so that the most appropriate comparisons in that experiment are within sex (Fig. 7). In experiment 1, XY ${ }^{-}$Sry males were more masculine (greater fiber density) than XXSry males, but $\mathrm{XY}^{-}$females were less masculine than XX females. Males had higher density of VP-ir fibers than females, which replicates the sex difference found consistently in rats and mice (Mayes et al., 1988; De Vries and AlShamma, 1990; Wang et al., 1993). The magnitude of this sex difference found in experiment 1 , however, could have been partly an artifact of staining differences caused by separate processing of male and female tissues. In experiment 2, all tissue was stained and analyzed at the same time. The difference between $\mathrm{XY}^{-}$Sry and XXSry males was replicated in experiment 2, but not the difference between $X Y^{-}$and $X X$ females. The three-way ANOVA showed a main effect of sex chromosomes $\left(F_{(1,85)}=4\right.$.9; $p=0.0296$ ), and a main effect of sex [males greater than females $\left.\left(F_{(1,85)}=90.6 ; p<0.000001\right)\right]$. Planned comparisons indicated that there was an effect of sex chromosomes in males but not 


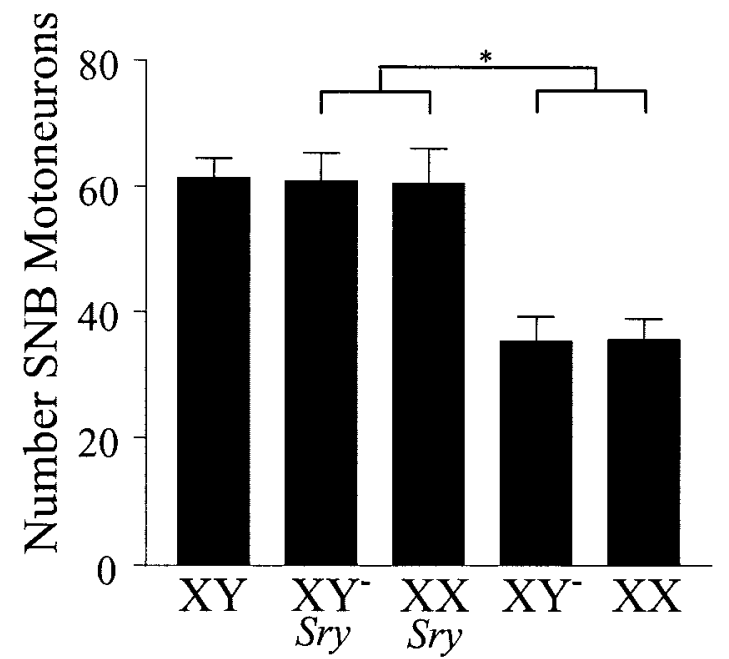

Figure 5. Number of SNB motoneurons (means \pm SEM). Males of the core cross $\left(\mathrm{XY}^{-}\right.$Sry and $\left.\mathrm{XXSry}\right)$ had more SNB neurons than females $\left(\mathrm{XY}^{-}\right.$and $\left.\mathrm{XX}\right)$ did $(p<0.0001)$ but did not differ from $\mathrm{XY}$ males derived from a different cross.

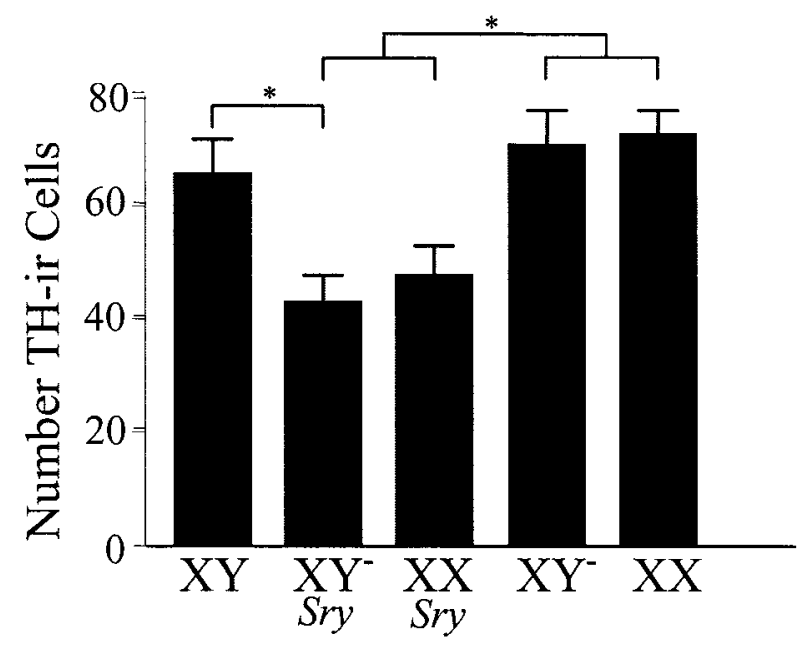

Figure 6. Number of TH-ir neurons in the AVPV (means \pm SEM). Within the core cross, males ( $\mathrm{XY}^{-}$Sry and $\mathrm{XXSry}$ ) had fewer neurons than females $\left(\mathrm{XY}^{-}\right.$and $\left.\mathrm{XX}\right)$ did $(p<0.000003)$. Paradoxically, $\mathrm{XY}$ males had a feminine number of TH-ir neurons and therefore significantly more TH-ir neurons than did $\mathrm{XY}^{-}$Sry males $(p=0.08)$.

females (Tukey-Kramer; $p<0.05$ ). There was a significant interaction of experiment number and sex chromosomes $\left(F_{(1,85)}=4.63\right.$; $p<0.034)$ because the difference between $\mathrm{XY}^{-}$and $\mathrm{XX}$, collapsing across sex, emerged in the second but not the first experiment (Tukey-Kramer; $p<0.05$ ). There was a significant interaction of experiment number and sex $\left(F_{(1,85)}=16.4 ; p<0.00012\right)$, which reflects the artificially larger difference between sexes in the first experiment than in the second experiment. There was no main effect of experiment number. There was no significant difference between $\mathrm{XY}$ and $\mathrm{XY}{ }^{-}$Sry males $\left(F_{(1,37)}=2.62 ; p>0.05\right)$.

Because $X^{-}$females had higher density of VP-ir fibers than $\mathrm{XX}$ females in experiment 2 but not experiment 1 , we examined this dependent variable in females derived from all-female litters in experiment 3. In this experiment, two batches of animals were stained and analyzed at different times and then compared in a single two-way ANOVA. XY ${ }^{-}$females had a significantly higher

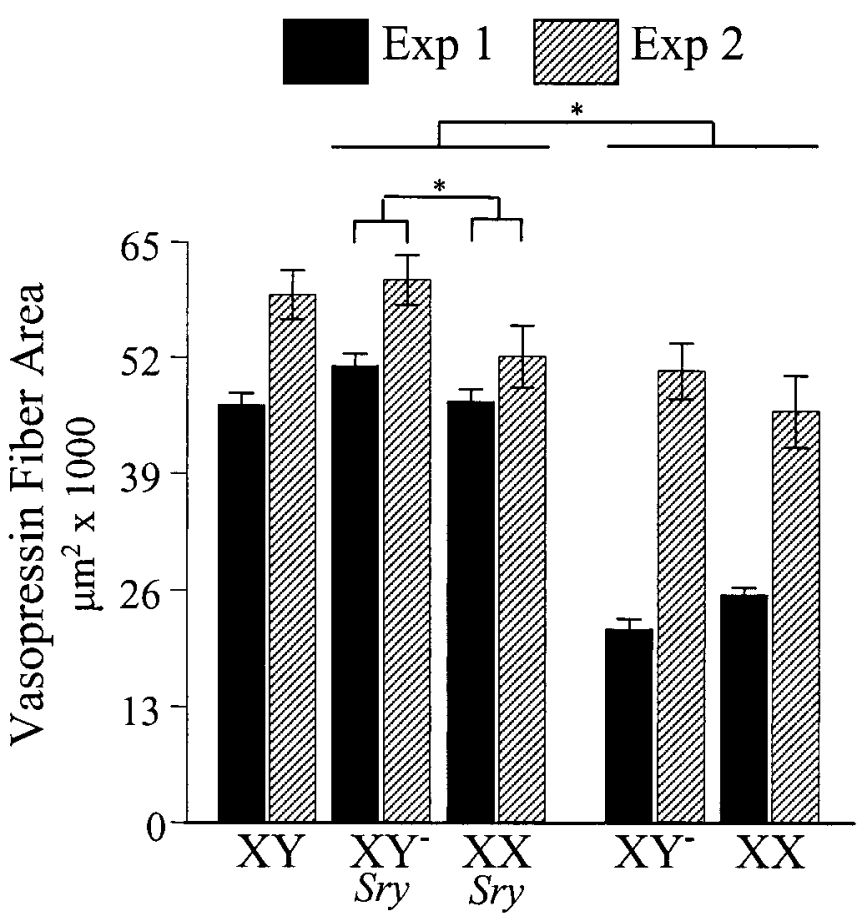

Figure 7. Density of vasopressin immunoreactive fibers in the lateral septum (means \pm SEM). Black and hatched bars represent the results from the first and second experiments, respectively. Within the core cross, males $\left(\mathrm{XY}^{-}\right.$Sry and XXSry) had a higher density than did females $(p<$ $0.000001)$. XY ${ }^{-}$Sry males had a higher density than XXSry males $(p<$ $0.05)$, showing an effect of sex chromosome complement on this trait.

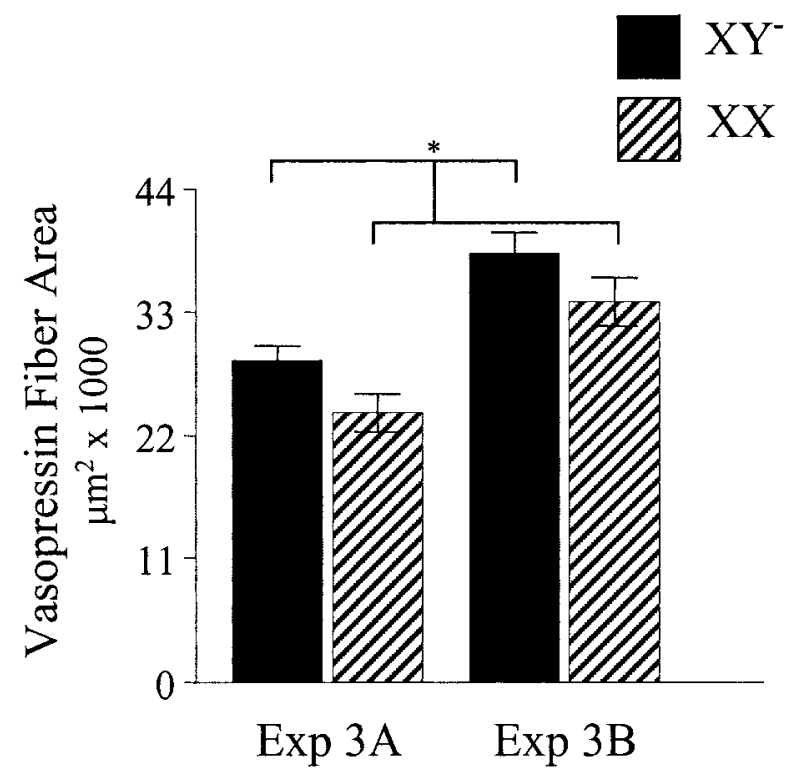

Figure 8. Density of vasopressin immunoreactive fibers in the lateral septum in mice from all-female litters (means \pm SEM). $X Y^{-}$females had a higher density than XX females did $(p<0.02)$.

density of VP-ir fibers than XX females $\left(F_{(1,43)}=6.37 ; p<0.02\right)$ (Fig. 8). There was no interaction between order of the experiment and genotype.

\section{DISCUSSION}

By measuring sexually dimorphic neural and behavioral traits in mice of one sex that possess different sex chromosomes (XY vs 
$\mathrm{XX}$ ), we hoped to determine whether the sex chromosomes contribute to normal sexual differentiation of the brain and behavior. Our hypothesis was that a masculine complement of sex chromosomes (XY) causes the brain to develop in a more masculine and less feminine manner, compared with a feminine complement $(\mathrm{XX})$. The panel of sexually dimorphic brain and behavioral phenotypes chosen for analysis included masculine copulatory and social behaviors known to be expressed more in males than females, and neural dimorphisms that are either male biased (SNB, septum) or female biased (AVPV) and occur at various levels of the neuraxis. Because development of these sexual dimorphisms is known in each case to be potently influenced by gonadal secretions (Wagner and Clemens, 1989; Wang et al., 1993; Rissman et al., 1997; Wersinger and Rissman, 2000a), we suspected that any effects of sex chromosomes might be subtle.

We detected an effect of the sex chromosomes on one measure, the density of VP-ir fibers in the lateral septum. XY ${ }^{-}$Sry males were more masculine on this trait than XXSry males, and when females from all-female litters were examined, $\mathrm{XY}^{-}$females were more masculine than $\mathrm{XX}$ females. In contrast, there was no effect of sex chromosomes on the other phenotypes in the $\mathrm{XX}$ females, $\mathrm{XY}^{-}$females, $\mathrm{XY}^{-}$Sry males, and XXSry males, although these phenotypes varied by sex. The results suggest that sex chromosome genes contribute to some sex-specific patterns of brain differentiation. However, this contribution appears to be much smaller for the traits analyzed than the organizing effects of gonadal hormones, because the differences between male and female mice of the same chromosomal sex were much larger than the differences between $\mathrm{XY}^{-}$and $\mathrm{XX}$ mice of the same sex. Because the relative variability in exposure to androgens from adjacent male fetuses is a plausible source of variability in the phenotype (vom Saal and Bronson, 1978), modest effects of intrauterine androgen may have masked the relatively smaller effects of sex chromosomes on VP-ir fiber density in females in the first experiment. The consistently higher VP-ir fiber density found in XY mice in the all-female litters in the third experiment supports this possibility. Because a masculine complement of sex chromosomes $\left(\mathrm{XY}^{-}\right)$led to greater masculinization of this trait than did a feminine complement $(\mathrm{XX})$, the difference between $\mathrm{XY}^{-}$and $\mathrm{XX}$ mice is in the same direction as the sex difference in this trait. Although we have emphasized direct sex chromosome gene influences on neural development, the difference between groups in the present experiments could be the result of sex chromosome gene actions on any tissue that influences neural development.

The sex chromosome effect could originate via a number of different genetic mechanisms. (1) Y genes (encoded on the nonrecombining region of the $\mathrm{Y}$ ) might masculinize the trait or inhibit feminine development. Sry and six other Y-linked genes are reported to be expressed in mouse brain (Kay et al., 1991; Agulnik et al., 1994; Zambrowicz et al., 1994; Lahr et al., 1995; Greenfield et al., 1996; Ehrmann et al., 1998; Mayer et al., 1998; Mazeyrat et al., 1998; Xu et al., 2002). The sex chromosome effect cannot be attributed to the action of Sry, however, because Sry was present as a transgene in the genome of both $\mathrm{XY}^{-}$Sry and XXSry males, and was absent in both female groups. (2) A double dose of one or more $\mathrm{X}$ genes might inhibit masculine development or promote feminine development of the trait in XX mice. Although most $X$ genes are thought to be expressed in a single dose in each XX somatic cell because of inactivation of one of the $\mathrm{X}$ chromosomes, some $\mathrm{X}$ genes escape inactivation (Carrel et al., 1999) and could therefore be present in the brain in a higher dose in $\mathrm{XX}$ than in $\mathrm{XY}$ mice, as has been documented for several $\mathrm{X}$ genes (Xu et al., 2002). The $X$ chromosome appears to have an unusually high number of genes implicated in brain-specific functions, which could contribute to the observed sex chromosome effect (Zechner et al., 2001). (3) Parent of origin effects (maternal or paternal imprinting) could activate or inactivate $\mathrm{X}$ chromosome genes differentially on maternally or paternally derived $\mathrm{X}$ chromosomes (Leighton et al., 1996; Skuse et al., 1997). Because $\mathrm{XY}^{-}$mice have only a maternally derived $\mathrm{X}$ chromosome, whereas XX mice have $\mathrm{X}$ chromosomes derived from both parents, these imprinting effects could give rise to different $X$ gene dosages in $\mathrm{XY}^{-}$versus $\mathrm{XX}$ brain.

The present data support the idea that a masculine genome has a masculinizing effect on the density of septal VP-ir fibers and that this sex chromosome effect is not found in other sexually dimorphic CNS systems (SNB and AVPV) or in several measures of reproductive and social behaviors mediated by diverse brain circuits. Might $\mathrm{XY}^{-}$and $\mathrm{XX}$ mice have experienced different levels of gonadal or adrenal steroids, so that this effect of the sex chromosomes represents merely another example of the well known masculinizing effects of testosterone? Indeed, perinatal testosterone injections masculinize septal VP fiber density in rats (Wang et al., 1993). The sex chromosome effect reported here, however, is unlikely to be mediated by group differences in androgen secretion. Had the $\mathrm{XY}^{-}$genotype caused a greater secretion of testosterone perinatally relative to the $\mathrm{XX}$ genotype, the difference in these groups should have been detected in more than one phenotype because most of the phenotypes measured are masculinized by testosterone or its metabolites, probably during different but overlapping critical periods (Vale et al., 1973; Wagner and Clemens, 1989; Wang et al., 1993; Simerly et al., 1997). Thus, each system can be considered a sensitive barometer of levels of gonadal steroids during perinatal development, and the lack of sex chromosome effects in most of the systems is evidence against a sex chromosome effect on the levels of circulating gonadal steroids. We conclude that the sex chromosome effect is specific to only one of the hormone-sensitive phenotypes that we measured and does not reflect a broad increase in steroid secretion or action. More interesting would be a sex chromosome effect on the cellular and molecular systems that respond to gonadal steroids (e.g., receptors, receptor cofactors, etc.), or on the level of sex steroid synthesis in the brain itself (Schlinger et al., 2001). Whatever the molecular mechanism, the sex chromosome effect does not require a masculine endocrine environment because it was detected in both males and females.

Previous results could be interpreted to suggest that factors other than gonadal hormones contribute to sex differences in VP-ir fiber density. In rats, neonatal gonadectomy of male rats reduced the VP-ir fiber density to the level of control females, whereas neonatal testosterone treatment prevented these changes. Neonatal testosterone treatment of females, however, failed to increase VP-ir fiber innervation to that of control males (Wang et al., 1993). Although this discrepancy in testosterone effect is consistent with a sex chromosomal effect on the sexual differentiation of VP-ir fiber density, prenatal gonadal hormone levels may have contributed to sex differences in testosterone sensitivity. Because it is difficult to mimic throughout development a female endocrine environment in XY males or a male endocrine environment in XX females, it has previously not been easy to eliminate sex differences in endocrine effects to focus on a role for the sex chromosomes in brain development. The genetic approach outlined in this paper therefore offers significant advan- 
tages for analyzing the relative contributions of sex chromosomal genes versus gonadal hormones in sexual differentiation.

The failure to find a sex chromosome effect on the number of TH-ir neurons in the AVPV in the present study might appear to conflict with the finding of Beyer et al. (1991) that female cultures of rat embryonic diencephalic neurons express higher levels of dopamine (see also Sibug et al., 1996). Because Beyer et al. (1991) attributed this sex difference to nonhormonal factors such as cell-autonomous actions of genes encoded on the sex chromosomes, one might have expected a sex chromosome effect on the number of TH-ir neurons in the AVPV. The lack of an effect could indicate, for example, that sex chromosome effects are exerted on diencephalic dopamine neurons in areas other than the AVPV, or that the effects found in vitro are not manifested in vivo (Reisert et al., 1990; Lieb et al., 1996). Interestingly, mesencephalic neurons from the same four sibling genotypes of the present experiment $\left(\mathrm{XY}^{-}, \mathrm{XX}, \mathrm{XY}^{-}\right.$Sry, XXSry) were recently grown in vitro using conditions similar to that of Beyer et al. (1991), and a strong sex chromosome effect could be detected (Carruth et al., 2002). That is, cultures consisting of $\mathrm{XY}^{-}$or $\mathrm{XY}^{-}$Sry cells developed more $\mathrm{TH}$-ir neurons than those derived from XX or XXSry cells, so that sex chromosome complement, not gonadal status of the embryos, was the major determinant of group differences in $\mathrm{TH}$ neuron number. It is not yet known whether this sex chromosome effect is found in dopamine neuron populations in vivo.

XY males differed from $\mathrm{XY}^{-}$Sry by several measures: latency to thrust, the number of total visits and visits to males in the social exploration tests, and the number of TH-ir AVPV neurons. These differences are potentially attributable either to the fact that XY and $\mathrm{XY}^{-}$Sry come from different crosses (thus the groups may have experienced different environments or had uncontrolled differences in genetic background) or to a difference in the effect of the Sry transgene versus that of endogenous Sry. The latter seems more likely, given that the nested litter analysis showed that the variation among litters within groups, which is the result of environment and chance genetic variation, is exceeded by the variation between litters across groups, where the difference in Sry comes into play. These behavioral differences could reflect Sry effects on the brain or other tissues. The Sry transgene mRNA may be expressed at higher levels in embryonic gonadal ridge than that encoded by the endogenous Sry (A. Swain, unpublished observations). Because the differences between XY and $\mathrm{XY}^{-}$Sry males were found in several but not all phenotypes, it is not clear whether the effect of Sry is mediated by an increase in androgen secretion or via a nonhormonal mechanism. Alternatively, the effects could be on nongonadal tissue outside of the brain. For example, the number of total visits and visits to males in the social exploration tests may be caused by differences in olfactory responsiveness (Paredes et al., 1998; Dominguez-Salazar et al., 2002). However, given that hypothalamic dopamine has been implicated in male sexual behavior (Hull et al., 1999), Sry effects on TH-ir neurons (Beyer et al., 1991) and male sexual behavior may be related.

Previous studies in mice have proved or suggested that the $\mathrm{Y}$ chromosome contains genes that influence various neural and behavioral traits, including aggressive behavior (Maxson et al., 1979; Maxson, 1992, 1999; Roubertoux et al., 1994; Guillot et al., 1995; Sluyter et al., 1996), the distribution of hippocampal mossy fibers (Hensbroek et al., 1995), dopamine systems (Sluyter et al., 1995), and brain serotonin (Tordjman et al., 1995). Moreover, Morris water maze learning performance has been reported to be more masculine in $\mathrm{C} 57 \mathrm{BL} / 6 \mathrm{~J} \mathrm{XY}^{\mathrm{POS}}$ female mice than in $\mathrm{XX}$ females (Stavnezer et al., 2000), although the fetal gonads of such females might contain some testicular tissue (Taketo et al., 1991), which could cause masculinization via a hormonal mechanism. These studies, together with the present findings, are consistent with a role for sex chromosome genes in neural and behavioral sexual differentiation. Interestingly, the same Y chromosomal factors that influence aggressive behavior (Sluyter et al., 1996) influence VP-ir fiber density in the lateral septum of mice selected for short or long attack latencies (Compaan et al., 1993) and may therefore have contributed to the differences found in the present study. These differences in VP-ir fiber density and aggressive behavior may also be causally related because VP has been implicated in aggressive behavior in rats and voles (Koolhaas et al., 1990, 1991; Winslow et al., 1993).

We have introduced a powerful model system for examining the separate and interactive effects of sex chromosomes and gonadal secretions on sexually dimorphic phenotypes. The dissociation of chromosomal and gonadal sex in these mice allows, for the first time, a strong test of the direct role of sex chromosomes in sexual differentiation of the brain and other somatic tissues. Importantly, these mice offer the ability to test the role of a masculine (XY) versus feminine (XX) complement of sex chromosomes under both masculine and feminine hormonal conditions. Group differences are sensitive to the effects of both X-and Y-linked genes. These mice will prove useful in further studies to investigate the role of sex chromosomes in differentiation of other sexually dimorphic phenotypes and the molecular basis for sex chromosome-induced somatic sexual differentiation.

Although the present results indicate that at least one sexual dimorphism in mouse brain is influenced by the complement of sex chromosome genes, the results are also compatible with the strong web of evidence that has already proven the dominant role for gonadal steroids in the induction of sex differences in brain and behavior (Arnold, 2002; De Vries and Simerly, 2002).

\section{REFERENCES}

Abercrombie M (1946) An estimation of nuclear population from microtomic sections. Anat Rec 94:239-247.

Agulnik AI, Mitchell MJ, Lerner JL, Woods DR, Bishop CE (1994) A mouse Y chromosome gene encoded by a region essential for spermatogenesis and expression of male-specific minor histocompatibility antigens. Hum Mol Genet 3:873-878.

Arnold AP (1997) Experimental analysis of sexual differentiation of the zebra finch brain. Brain Res Bull 44:503-507.

Arnold AP (2002) Concepts of genetic and hormonal induction of vertebrate sexual differentiation in the 20th century, with special reference to the brain. In: Hormones, brain, and behavior, Vol IV. Development of hormone-dependent neuronal systems (Pfaff DW, Arnold AP, Etgen AM, Fahrbach SE, Moss RL, Rubin RT, eds), pp 105-135. San Diego: Academic.

Arnold AP, Gorski RA (1984) Gonadal steroid induction of structural sex differences in the CNS. Annu Rev Neurosci 7:413-442.

Beyer C, Pilgrim C, Reisert I (1991) Dopamine content and metabolism in mesencephalic and diencephalic cell cultures: sex differences and effects of sex steroids. J Neurosci 11:1325-1333.

Beyer C, Kolbinger W, Froehlich U, Pilgrim C, Reisert I (1992a) Sex differences of hypothalamic prolactin cells develop independently of the presence of sex steroids. Brain Res 593:253-256.

Beyer C, Eusterschulte B, Pilgrim C, Reisert I (1992b) Sex steroids do not alter sex differences in tyrosine hydroxylase activity of dopaminergic neurons in vitro. Cell Tissue Res 270:547-552.

Breedlove SM, Arnold AP (1980) Hormone accumulation in a sexually dimorphic motor nucleus of the rat spinal cord. Science 210:564-566.

Burgoyne PS, Thornhill AR, Boudrean SK, Darling SM, Bishop CE, Evans EP (1995) The genetic basis of XX-XY differences present before gonadal sex differentiation in the mouse. Philos Trans R Soc Lond B Biol Sci 350:253-260.

Carrel L, Cottle AA, Goglin KC, Willard HF (1999) A first-generation $\mathrm{X}$-inactivation profile of the human X chromosome. Proc Natl Acad Sci USA 96:14440-14444. 
Carruth LC, Reisert I, Arnold AP (2002) Direct effect of sex chromosome genes on brain sexual differentiation. Nat Neurosci, in press.

Compaan JC, Buijs RM, Pool CW, De Ruiter AJ, Koolhaas JM (1993) Differential lateral septal vasopressin innervation in aggressive and nonaggressive male mice. Brain Res Bull 30:1-6.

Conway SJ, Mahadevaiah SK, Darling SM, Capel B, Rattigan AM, Burgoyne PS (1994) Y353/B: a candidate multiple-copy spermiogenesis gene on the mouse Y chromosome. Mamm Genome 5:203-210.

Dulai KS, von Dornum M, Mollon JD, Hunt DM (1999) The evolution of trichromatic color vision by opsin gene duplication in New World and Old World primates. Genome Res 9:629-638.

De Vries GJ, Al-Shamma HA (1990) Sex differences in hormonal responses of vasopressin pathways in the rat brain. J Neurobiol 21:686-693

De Vries GJ, Simerly RB (2002) Anatomy, development, and function of sexually dimorphic neural circuits in the mammalian brain. In: Hormones, brain, and behavior, Vol IV. Development of hormonedependent neuronal systems (Pfaff DW, Arnold AP, Etgen AM, Fahrbach SE, Moss RL, Rubin RT, eds), pp 137-191. San Diego: Academic.

Dominguez-Salazar E, Portillo W, Baum MJ, Bakker J, Paredes RG (2002) Effect of prenatal androgen receptor antagonist or aromatase inhibitor on sexual behavior, partner preference and neuronal Fos responses to estrous female odors in the rat accessory olfactory system. Physiol Behav 75:337-346.

Ehrmann IE, Ellis PS, Mazeyrat S, Duthie S, Brockdorff N, Mattei MG, Gavin MA, Affara NA, Brown GM, Simpson E, Mitchell MJ, Scott DM (1998) Characterization of genes encoding translation initiation factor eIF-2gamma in mouse and human: sex chromosome localization, escape from X-inactivation and evolution. Hum Mol Genet 7:1725-1737.

Erickson RP (1997) Does sex determination start at conception? BioEssays 19:1027-1032.

Ericson J, Thor S, Edlund T, Jessell TM, Yamada T (1992) Early stages of motor neuron differentiation revealed by expression of homeobox gene Islet-1. Science 256:1555-1560.

Ericson J, Morton S, Kawakami A, Roelink H, Jessell TM (1996) Two critical periods of Sonic Hedgehog signaling required for the specification of motor neuron identity. Cell 87:661-673.

Goodfellow PN, Lovell-Badge R (1993) Sry and sex determination in mammals. Annu Rev Genet 27:71-92.

Goy RW, McEwen BS (1980) Sexual differentiation of the brain. Cambridge, MA: MIT.

Greenfield A, Scott D, Pennisi D, Ehrmann I, Ellis P, Cooper L, Simpson E, Koopman P (1996) An H-YDb epitope is encoded by a novel mouse Y chromosome gene. Nat Genet 14:474-478.

Gubbay J, Vivian N, Economou A, Jackson D, Goodfellow P, LovellBadge R (1992) Inverted repeat structure of the Sry locus in mice. Proc Natl Acad Sci USA 89:7953-7957.

Guillot PV, Carlier M, Maxson SC, Roubertoux PL (1995) Intermale aggression tested in two procedures, using four inbred strains of mice and their reciprocal congenics: Y chromosomal implications. Behav Genet 25:357-360.

Hauser KF, Toran-Allerand CD (1989) Androgen increases the number of cells in fetal mouse spinal cord cultures: implications for motoneuron survival. Brain Res 485:157-164.

Hensbroek RA, Sluyter F, Guillot PV, Van Oortmerssen GA, Crusio WE (1995) Y chromosomal effects on hippocampal mossy fiber distributions in mice selected for aggression. Brain Res 682:203-206.

Hull EM, Lorrain DS, Du J, Matuszewich L, Lumley LA, Putnam SK, Moses J (1999) Hormone-neurotransmitter interactions in the control of sexual behavior. Behav Brain Res 105:105-116.

Jacobs GH (1998) A perspective on color vision in platyrrhine monkeys. Vision Res 38:3307-3313.

Jost A (1958) Embryonic sexual differentiation. In: Hermaphroditism, genital anomalies, and related endocrine disorders (Jones HW, Scott WW, eds), pp 15-45. Baltimore: Williams \& Wilkins.

Kay GF, Ashworth A, Penny GD, Dunlop M, Swift S, Brockdorff N, Rastan S (1991) A candidate spermatogenesis gene on the mouse $Y$ chromosome is homologous to ubiquitin-activating enzyme E1. Nature $354: 486-489$

Koolhaas JM, Van den Brink THC, Roozendaal B, Boorsma F (1990) Medial amygdala and aggressive behavior: interaction between testosterone and vasopressin. Aggressive Behav 16:223-229.

Koolhaas JM, Moor E, Hiemstra Y, Bohus B (1991) The testosteronedependent vasopressinergic neurons in the medial amygdala and lateral septum: involvement in social behaviour of male rats. In: Vasopressin, Colloque INSERM, Vol 208 (Jard S, Jamison R, eds), pp 213-219. Montrouge, France: John Libbey Eurotext.

Lahr G, Maxson SC, Mayer A, Just W, Pilgrim C, Reisert I (1995) Transcription of the Y chromosomal gene, Sry, in adult mouse brain. Mol Brain Res 33:179-182.

Leighton PA, Saam JR, Ingram RS, Tilghman SM (1996) Genomic imprinting in mice: its function and mechanism. Biol Reprod 54:273-278.

Lieb K, Andersen C, Lazarov N, Zienecker R, Urban I, Reisert I, Pilgrim C (1996) Pre- and postnatal development of dopaminergic neuron numbers in the male and female mouse midbrain. Dev Brain Res 94:37-43.

Lovell-Badge R, Robertson E (1990) XY female mice resulting from a heritable mutation in the primary testis-determining gene, $T d y$. Development 109:635-646.

Mahadevaiah SK, Lovell-Badge R, Burgoyne PS (1993) Tdy-negative XY, XXY and XYY female mice: breeding data and synaptonemal complex analysis. J Reprod Fertil 97:151-160.

Mahadevaiah SK, Odorisio T, Elliott DJ, Rattigan A, Szot M, Laval SH, Washburn LL, McCarrey JR, Cattanach BM, Lovell-Badge R, Burgoyne PS (1998) Mouse homologues of the human AZF candidate gene RBM are expressed in spermatogonia and spermatids, and map to a Y chromosome deletion interval associated with a high incidence of sperm abnormalities. Hum Mol Genet 7:715-727.

Mahadevaiah SK, Evans EP, Burgoyne PS (2000) An analysis of meiotic impairment and of sex chromosome associations throughout meiosis in xyy mice. Cytogenet Cell Genet 89:29-37.

Maxson SC (1992) Methodological issues in genetic analyses of an agonistic behavior (offense) in male mice. In: Techniques for the genetic analysis of brain and behavior (Goldowitz D, Wahisten D, Wimer RE, eds), pp 349-373. New York: Elsevier.

Maxson SC (1996a) Issues in the search for candidate genes in mice as potential animal models of human aggression. Ciba Found Symp 194:21-35.

Maxson SC (1996b) Searching for candidate genes with effects on an agonistic behavior, offense, in mice. Behav Genet 26:471-476.

Maxson SC (1999) Sex differences in genetic mechanisms for mammalian brain and behavior. Biomed Rev 7:85-90.

Maxson SC, Ginsburg BE, Trattner A (1979) Interaction of Y-chromosomal and autosomal gene(s) in the development of intermale aggression in mice. Behav Genet 9:219-226.

Mayer A, Lahr G, Swaab DF, Pilgrim C, Reisert I (1998) The Y-chromosomal genes Sry and ZFY are transcribed in adult human brain. Neurogenetics 1:281-288.

Mayes CR, Watts AG, McQueen JK, Fink G, Charlton HM (1988) Gonadal steroids influence neurophysin II distribution in the forebrain of normal and mutant mice. Neuroscience 25:1013-1022.

Mazeyrat S, Saut N, Sargent CA, Grimmond S, Longepied G, Ehrmann IE, Ellis PS, Greenfield A, Affara NA, Mitchell MJ (1998) The mouse $\mathrm{Y}$ chromosome interval necessary for spermatogonial proliferation is gene dense with syntenic homology to the human AZFa region. Hum Mol Genet 7:1713-1724.

Paredes RG, Lopez ME, Baum MJ (1998) Testosterone augments neuronal Fos responses to estrous odors throughout the vomeronasal projection pathway of gonadectomized male and female rats. Horm Behav 33:48-57.

Paxinos G, Franklin KBJ (1998) The mouse brain in stereotaxic coordinates, Ed 2. San Diego: Academic.

Phoenix CH, Goy RW, Gerall AA, Young WC (1959) Organizing action of prenatally administered testosterone propionate on the tissues mediating mating behavior in the female guinea pig. Endocrinology 65:369-382.

Ratcliffe SG, Butler GE, Jones M (1990) Edinburgh study of growth and development of children with sex chromosome abnormalities In: Children and young adults with sex chromosome aneuploidy: follow-up (Evans JA, Hamerton JL, Robinson A, eds), pp 1-44, New York: Wiley.

Reisert I, Schuster R, Zienecker R, Pilgrim C (1990) Prenatal development of mesencephalic and diencephalic dopaminergic systems in the male and female rat. Dev Brain Res 53:222-229.

Renfree MB, Short RV (1988) Sex determination in marsupials: evidence for a marsupial-eutherian dichotomy. Philos Trans R Soc Lond B Biol Sci 322:41-53.

Rissman EF, Early AE, Taylor JA, Korach KS, Lubahn DB (1997) Estrogen receptors are essential for female sexual receptivity. Endocrinology 138:507-510.

Roubertoux PL, Carlier M, Digrelle H, Haas-Dupertuis M-C, Phillips J, Moutier R (1994) Co-segregation of intermale aggression with the pseudoautosomal region of the $\mathrm{Y}$ chromosome in mice. Genetics 135:225-230.

Sawchenko PE, Swanson LW (1981) A method for tracing biochemically defined pathways in the central nervous system using combined fluorescence retrograde transport and immunohistochemical techniques. Brain Res 210:31-51.

Schlinger BA, Soma KK, London SE (2001) Neurosteroids and brain sexual differentiation. Trends Neurosci 24:429-431.

Schmued LC, Swanson LW, Sawchenko PE (1982) Some fluorescent counterstains for neuroanatomical studies. J Histochem Cytochem 30:123-128.

Sibug R, Kuppers E, Beyer C, Maxson SC, Pilgrim C, Reisert I (1996) Genotype-dependent sex differentiation of dopaminergic neurons in primary cultures of embryonic mouse brain. Dev Brain Res 31:136-142.

Simerly RB, Zee MC, Pendleton JW, Lubahn DB, Korach KS (1997) Estrogen receptor-dependent sexual differentiation of dopaminergic 
neurons in the preoptic region of the mouse. Proc Natl Acad Sci USA 94:14077-14082.

Simpson EM, Linder CC, Sargent EE, Davisson MT, Mobraaten LE, Sharp JJ (1999) Genetic variation among 129 substrains and its importance for targeted mutagenesis in mice. Nat Genet 16:19-27.

Skuse DH, James RS, Bishop DVM, Coppin B, Dalton P, AamodtLeeper G, Bacarese-Hamilton M, Creswell C, McGurk R, Jacobs PA (1997) Evidence from Turner's syndrome of an imprinted X-linked locus affecting cognitive function. Nature 387:705-708.

Sluyter F, Bohus B, Beldhuis HJA, Van Oortmerssen GA (1995) Autosomal and Y chromosomal effects on the stereotyped response to apomorphine in wild house mice. Pharmacol Biochem Behav 52:17-22.

Sluyter F, Van Oortmerssen GA, De Ruiter AJH, Koolhaas JM (1996) Aggression in wild house mice: current state of affairs. Behav Genet 26:489-496.

Stavnezer AJ, McDowell CS, Hyde LA, Bimonte HA, Balogh SA, Denenberg VH (2000) Spatial ability of XY sex-reversed female mice. Behav Brain Res 112:135-143.

Taketo T, Saeed J, Nishioka Y, Donahoe PK (1991) Delay of testicular differentiation in the B6.YDOM ovotestis demonstrated by immunocytochemical staining for mullerian inhibiting substance. Dev Biol 146:386-395.

Tordjman S, Roubertoux PL, Carlier M, Moutier R, Anderson G, Launay M, Degrelle H (1995) Linkage between brain serotonin concentration and the sex-specific part of the Y-chromosome in mice. Neurosci Lett 183:190-192.

Vale R, Ray D, Vale CA (1973) Neonatal androgen treatment and sexual behavior in males of three inbred strains of mice. Dev Psychobiol 7:483-488.

Villalba C, Auger CJ, De Vries GJ (1999) Androstenedione effects on the vasopressin innervation of the rat brain. Endocrinology 140:3383-3386.

vom Saal FS, Bronson FH (1978) In utero proximity of female mouse fetuses to males: effect on reproductive performance during later life. Biol Reprod 19:842-853.

Wade J, Arnold AP (1996) Functional testicular tissue does not mascu- linize development of the zebra finch song system. Proc Natl Acad Sci USA 93:5264-5268.

Wagner CK, Clemens LG (1989) Perinatal modification of a sexually dimorphic motor nucleus in the spinal cord of the B6D2F1 house mouse. Physiol Behav 45:831-835.

Wang Z, Bullock NA, De Vries GJ (1993) Sexual differentiation of vasopressin projections of the bed nucleus of the stria terminals and medial amygdaloid nucleus in rats. Endocrinology 132:2299-2306.

Wee BEF, Clemens LG (1987) Characteristics of the spinal nucleus of the bulbocavernosus are influenced by genotype in the house mouse. Brain Res 424:305-310.

Wersinger SR, Rissman EF (2000a) Dopamine activates masculine sexual behavior independent of the estrogen receptor $\alpha$. J Neurosci 20:4248-4254.

Wersinger SR, Rissman EF (2000b) Oestrogen receptor alpha is essential for female-directed chemo-investigatory behaviour but is not required for the pheromone-induced luteinizing hormone surge in male mice. J Neuroendocrinol 12:103-110.

Wersinger SR, Sannen K, Villalba C, Lubahn DB, Rissman EF, De Vries GJ (1997) Masculine sexual behavior is disrupted in male and female mice lacking a functional estrogen receptor alpha gene and behavioral aspects. Horm Behav 32:176-183.

Winslow JT, Hastings N, Carter CS, Harbaugh CR, Insel TR (1993) A role for central vasopressin in pair bonding in monogamous prairie voles. Nature 365:545-547.

Xu J, Burgoyne PS, Arnold AP (2002) Sex differences in sex chromosome gene expression in mouse brain. Hum Mol Genet 11:1409-1419.

Zambrowicz BP, Zimmermann JW, Harendza CJ, Simpson EM, Page DC, Brinster RL, Palmiter RD (1994) Expression of a mouse Zfy-1/ lacZ transgene in the somatic cells of the embryonic gonad and germ cells of the adult testis. Development 120:1549-1559.

Zechner U, Wilda M, Kehrer-Sawatzki H, Vogel W, Fundele R, Hameister H (2001) A high density of X-linked genes for general cognitive ability: a run-away process shaping human evolution? Trends Genet 17:697-701. 